\title{
CCCS-SSAI WikiRecs Clinical Practice Guideline: vasopressor blood pressure targets in critically ill adults with hypotension
}

\author{
Bram Rochwerg, MD (D) Mathieu Hylands, MD • Morten Møller, MD • Pierre Asfar, MD • Dian Cohen • \\ Rachel G. Khadaroo, MD · John H. Laake, MD • Anders Perner, MD • Teddie Tanguay, RN • Sandy Widder, MD • \\ Per Vandvik, MD • Annette Kristiansen, MD • François Lamontagne, MD
}

Received: 29 July 2016/Revised: 16 October 2016/Accepted: 11 April 2017/Published online: 11 May 2017

(C) Canadian Anesthesiologists' Society 2017

PICO $^{\text {A }}$ Question: In adult critically ill patients with hypotension and requiring vasopressor support, should we be prescribing a higher blood pressure target (MAP 75-85) when compared with a lower blood pressure target (MAP 60-70)?

Recommendation: We suggest against the use of a higher blood pressure (BP) target (MAP 75-85) when compared with a lower BP target (MAP 60-70) in adult critically ill patients with hypotension and requiring vasopressors. (Conditional recommendation)

This is a recommendation developed by the Canadian Critical Care Society and the Scandinavian Society of Anaesthesiology and Intensive Care Medicine according to standards for trustworthy guidelines in collaboration with the MAGIC WikiRecs project. An abridged version of the guideline is published in Intensive Care Medicine (10.1007/s00134-016-4539-5).

This article is accompanied by an editorial. Please see Can J Anesth 2017; 64: this issue.

Electronic supplementary material The online version of this article (doi:10.1007/s12630-017-0878-0) contains supplementary material, which is available to authorized users.

B. Rochwerg, MD $(\bowtie)$

Department of Medicine, Faculty of Health Sciences, McMaster

University, Hamilton, ON, Canada

e-mail: rochwerg@mcmaster.ca

\section{B. Rochwerg, MD}

Department of Clinical Epidemiology and Biostatistics, McMaster

University, Hamilton, ON, Canada

M. Hylands, MD · F. Lamontagne, MD

Université de Sherbrooke, Sherbrooke, QC, Canada

M. Møller, MD · A. Perner, MD

Department of Intensive Care, Copenhagen University Hospital

Rigshospitalet, Copenhagen, Denmark
This is a recommendation developed by the Canadian Critical Care Society and the Scandinavian Society of Anaesthesiology and Intensive Care Medicine (CCCS-SSAI) according to standards for trustworthy guidelines in collaboration with the MAGIC WikiRecs project. The WikiRecs project is an ongoing collaborative effort by a network of expert clinicians and methodologists whose aim is to produce trustworthy evidence summaries and clinical practice recommendations within 90 days of identifying potentially practice-changing evidence. See www. magicapp.org/public/guideline/OLwWKL for more details about methods and processes, full evidence summary (GRADE SoF-table), and practical information presented in multilayered formats-available on all digital devices. The electronic supplemental material also contains similar information expanding on the WikiRecs methods and processes.

P. Asfar, MD

Medical Intensive Care Department, University Hospital of Angers, Angers, France

D. Cohen

Massawippi Valley Health Centre, Ayers Cliff, QC, Canada

R. G. Khadaroo, MD - S. Widder, MD

Department of Surgery and Critical Care Medicine, University of Alberta, Edmonton, AB, Canada

\footnotetext{
A PICO is defined as: Population, Intervention, Comparator, Outcome.
} 
Table Evidence profile outcomes studied, pooled relative and absolute estimates of effect, GRADE certainty rating, and summary statement

\begin{tabular}{|c|c|c|c|c|}
\hline \multirow{2}{*}{ Outcome } & \multirow{2}{*}{$\begin{array}{l}\text { Study results and } \\
\text { measurements }\end{array}$} & Absolute effect estimates & \multirow{2}{*}{$\begin{array}{l}\text { Certainty in effect estimates } \\
\text { (Quality of evidence) }\end{array}$} & \multirow{2}{*}{ Summary } \\
\hline & & $\begin{array}{ll}\text { Lower MAP target } & \text { Higher MAP target } \\
(60-70 \mathrm{mmHg}) & (75-85 \mathrm{mmHg})\end{array}$ & & \\
\hline $\begin{array}{l}\text { Short-term Mortality } \\
\text { ( } 90 \text { days) }\end{array}$ & $\begin{array}{l}\text { Relative risk: } 1.05 \\
(95 \% \text { CI } 0.9 \text { to } 1.23) \\
\text { Based on data from } 894 \\
\text { patients in } 2 \text { studies }\end{array}$ & $\begin{array}{l}411 \text { per } 1,000 \quad 433 \text { per } 1,000 \\
\text { Difference: } 21 \text { more deaths per } 1,000 \\
(95 \% \text { CI, }-41 \text { to } 94)\end{array}$ & $\begin{array}{l}\text { Low } \\
\text { Due to serious imprecision and } \\
\text { serious risk of bias }\end{array}$ & $\begin{array}{l}\text { Higher MAP target ( } 75-85 \\
\mathrm{mmHg} \text { ) probably made little or no } \\
\text { difference on short-term mortality }\end{array}$ \\
\hline $\begin{array}{l}\text { Long-term Mortality }> \\
90 \text { days } \\
\text { ( } 6 \text { months) }\end{array}$ & $\begin{array}{l}\text { Relative risk: } 1.13 \\
\text { (95\% CI } 0.72 \text { to } 1.77) \\
\text { Based on data from } 118 \\
\text { patients in } 1 \text { study }\end{array}$ & $\begin{array}{l}367 \text { per } 1,000 \quad 414 \text { per } 1,000 \\
\text { Difference: } 47 \text { more deaths per } 1,000 \\
(95 \% \text { CI, }-103 \text { to } 282)\end{array}$ & $\begin{array}{l}\text { Low } \\
\text { Due to serious risk of bias and } \\
\text { serious imprecision }\end{array}$ & $\begin{array}{l}\text { Higher MAP target ( } 75-85 \\
\text { mmHg) probably made little or no } \\
\text { difference on long-term mortality } \\
>90 \text { days }\end{array}$ \\
\hline $\begin{array}{l}\text { Use of Renal } \\
\text { Replacement Therapy } \\
\text { (RRT) } \\
\text { ( } 28 \text { days) }\end{array}$ & $\begin{array}{l}\text { Relative risk: } 0.96 \\
\text { (95\% CI } 0.80 \text { to } 1.14) \\
\text { Based on data from } 894 \\
\text { patients in } 2 \text { studies }\end{array}$ & $\begin{array}{l}357 \text { per } 1,000 \quad 343 \text { per } 1,000 \\
\text { Difference: } 25 \text { fewer patients needing RRT per } 1,000 \\
(95 \% \mathrm{CI},-71 \text { to } 50)\end{array}$ & $\begin{array}{l}\text { Low } \\
\text { Due to serious risk of bias and } \\
\text { serious imprecision }\end{array}$ & $\begin{array}{l}\text { Higher MAP target ( } 75-85 \\
\text { mmHg) probably made little or no } \\
\text { difference on use of renal } \\
\text { replacement therapy }\end{array}$ \\
\hline $\begin{array}{l}\text { Digit, Limb or Skin } \\
\text { Ischemia }\end{array}$ & $\begin{array}{l}\text { Relative risk: } 0.95 \\
\text { (95\% CI } 0.41 \text { to } 2.16 \text { ) } \\
\text { Based on data from } 894 \\
\text { patients in } 2 \text { studies }\end{array}$ & $\begin{array}{l}27 \text { per } 1,000 \\
\text { Difference: } 1 \text { less episode of ischemia per } 1,000 \\
(95 \% \mathrm{CI},-16 \text { to } 31)\end{array}$ & $\begin{array}{l}\text { Very Low } \\
\text { Due to serious risk of bias and very } \\
\text { serious imprecision }\end{array}$ & $\begin{array}{l}\text { We are uncertain whether a higher } \\
\text { MAP target }(75-85 \mathrm{mmHg}) \\
\text { increases or decreases digit, limb, } \\
\text { or skin ischemia }\end{array}$ \\
\hline $\begin{array}{l}\text { Myocardial Ischemia } \\
\text { (MI) }\end{array}$ & $\begin{array}{l}\text { Relative risk: } 1.46 \\
\text { (95\% CI } 0.38 \text { to } 5.64) \\
\text { Based on data from } 894 \\
\text { patients in } 2 \text { studies }\end{array}$ & $\begin{array}{l}29 \text { per } 1,000 \quad 36 \text { per } 1,000 \\
\text { Difference: } 13 \text { more MIs per } 1,000 \\
(95 \% \text { CI, }-18 \text { to } 135)\end{array}$ & $\begin{array}{l}\text { Very Low } \\
\text { Due to serious risk of bias and very } \\
\text { serious imprecision }\end{array}$ & $\begin{array}{l}\text { We are uncertain whether a higher } \\
\text { MAP target }(75-85 \mathrm{mmHg}) \\
\text { increases or decreases myocardial } \\
\text { ischemia }\end{array}$ \\
\hline $\begin{array}{l}\text { Ventilator-free Days } \\
\text { (VFD) } \\
\text { ( } 28 \text { days) }\end{array}$ & $\begin{array}{l}\text { Based on data from } 894 \\
\text { patients in } 2 \text { studies }\end{array}$ & $\begin{array}{l}15.9 \text { (Mean) } \\
\text { Mean Difference: } 0.84 \text { fewer VFDs } \\
(95 \% \mathrm{CI},-2.28 \text { to } 0.6)\end{array}$ & $\begin{array}{l}\text { Low } \\
\text { Due to serious risk of bias and } \\
\text { serious imprecision }\end{array}$ & $\begin{array}{l}\text { A higher MAP target }(75-85 \\
\mathrm{mmHg} \text { ) probably made little or no } \\
\text { difference on ventilator-free days }\end{array}$ \\
\hline
\end{tabular}

MAP = mean arterial pressure $\mathbf{C I}=$ confidence interval

Justification: We developed this recommendation according to the standards for trustworthy guidelines, including a systematic review that identified two randomized-controlled trials (894 patients) relevant to our

\section{J. H. Laake, MD}

Anaesthesiology, Division of Critical Care, Oslo University Hospital, Oslo, Norway

\section{T. Tanguay, RN}

Canadian Association of Critical Care Nurses, Edmonton, AB, Canada

P. Vandvik, MD · A. Kristiansen, MD

Faculty of Medicine, University of Oslo, Oslo, Norway

\section{P. Vandvik, MD}

Norwegian Knowledge Centre for the Health Services, Oslo, Norway

\section{P. Vandvik, MD - A. Kristiansen, MD}

Department of Medicine, Innlandet Hospital Trust-Division, Gjøvik, Norway

\section{F. Lamontagne, MD}

Centre de recherche du Centre Hospitalier Universitaire de Sherbrooke, Sherbrooke, QC, Canada clinical question. ${ }^{1,2}$ The larger trial included only patients with hypotension secondary to sepsis, ${ }^{1}$ whereas the other trial enrolled patients with distributive shock due to any etiology. ${ }^{2}$

Our weak recommendation against higher BP targets takes into consideration the absence of a demonstrated benefit and high resource demands associated with higher dose or longer duration vasopressor infusions (see Table). Additionally, it may be that the prescription of higher thresholds, and a subsequent need for higher doses of vasopressors to achieve these thresholds, leads to increased harm via increased myocardial ischemia and tachyarrhythmias. Nevertheless, this signal is limited by imprecision and risk of bias. This signal for harm may be more substantive in the elderly population based on subgroup analysis; however, the panel did not consider the evidence robust enough for a stronger recommendation in this population.

All outcome data were based on low or very low certainty evidence and, as such, the panel refrained from making a more definitive recommendation. The residual uncertainty was a result of lack of blinding of group allocation in the individual studies and imprecision of the 
pooled results. The guideline panel had significant internal debate as regards lowering the overall certainty for lack of blinding (risk of bias) in view of the objective nature of mortality as an outcome and the impracticalities of blinding an intervention such as BP targets. Other than lack of blinding, both trials had a low risk of bias for all other domains included in the Cochrane randomized-controlled trials tool. ${ }^{3}$ Ultimately, as intensive care unit mortality is often the result of end-of-life decision-making ${ }^{4}$ and in order to remain conservative in our overall certainty judgement, we decided to lower for risk of bias due to lack of blinding.

The guideline panel also acknowledged the difficulty in making recommendations without quality of life particulars, morbidity indices, or long-term outcome data. Prescribing higher BP targets may have had a different impact on these outcomes than on mortality, and therefore, may have affected our overall recommendation. Our patient representative identified this factor as a significant limitation, and this represents an important consideration for future research in this area.

Conflict of interest None declared.

Editorial responsibility This submission was handled by $\mathrm{Dr}$. Hilary P. Grocott, Editor-in-Chief, Canadian Journal of Anesthesia.
Author contributions Bram Rochwerg contributed by chairing the guideline panel, helping to employ GRADE methodology and certainty of evidence assessments, and drafting the manuscript. Mathieu Hylands and Francois Lamontagne coordinated the evidence search and synthesis and were guideline panel members. Annette Kristiansen was the methods chair for the guideline panel. Morten Moller, Pierre Asfar, Dian Cohen, Rachel Khadaroo, Jon Laake, Anders Perner, Teddie Tanguay, Sandy Widder, and Per Vandvik were panel members, contributed significantly to formulating the recommendation, and provided edits to the manuscript.

\section{References}

1. Asfar P, Meziani F, Hamel JF, et al. High versus low bloodpressure target in patients with septic shock. N Engl J Med 2014; 370: 1583-93.

2. Lamontagne F, Meade MO, Hebert PC, et al. Higher versus lower blood pressure targets for vasopressor therapy in shock: a multicentre pilot randomized controlled trial. Intensive Care Med 2016; 42: 542-50.

3. Higgins JP, Altman DG, Gotzsche PC, et al. The Cochrane Collaboration's tool for assessing risk of bias in randomised trials. BMJ 2011; 343: d5928.

4. Mehter HM, Wiener RS, Walkey AJ. "Do not resuscitate" decisions in acute respiratory distress syndrome. A secondary analysis of clinical trial data. Ann Am Thorac Soc 2014; 11: 1592-6. 